Portland State University

PDXScholar

\title{
The Built Environment, Neighborhood Safety, and Physical Activity among Low Income Children
}

Jessica Greene

University of Oregon

Debbie Daniel

University of Oregon

Follow this and additional works at: https://pdxscholar.library.pdx.edu/trec_reports

Part of the Social Welfare Commons, and the Urban Studies Commons Let us know how access to this document benefits you.

\section{Recommended Citation}

Jessica Greene \& Debbie Daniel. The Built Environment, Neighborhood Safety, and Physical Activity among Low Income Children. OTREC-RR-09-06. Portland, OR: Transportation Research and Education Center (TREC) 2009. https://doi.org/10.15760/trec.101

This Report is brought to you for free and open access. It has been accepted for inclusion in TREC Final Reports by an authorized administrator of PDXScholar. Please contact us if we can make this document more accessible: pdxscholar@pdx.edu. 


\section{SOTREC}

FINAL REPORT

\section{The Built Environment, Neighborhood Safety, and Physical Activity Among Low-Income Children} OTREC-RR-09-06
September 2009 OTREC-RR-09-06
September 2009 



\title{
THE BUILT ENVIRONMENT, NEIGHBORHOOD SAFETY, AND PHYSICAL ACTIVITY AMONG LOW-INCOME CHILDREN
}

\author{
Final Report \\ OTREC-RR-09-06 \\ by \\ Jessica Greene \\ Debbie Daniel \\ University of Oregon
}

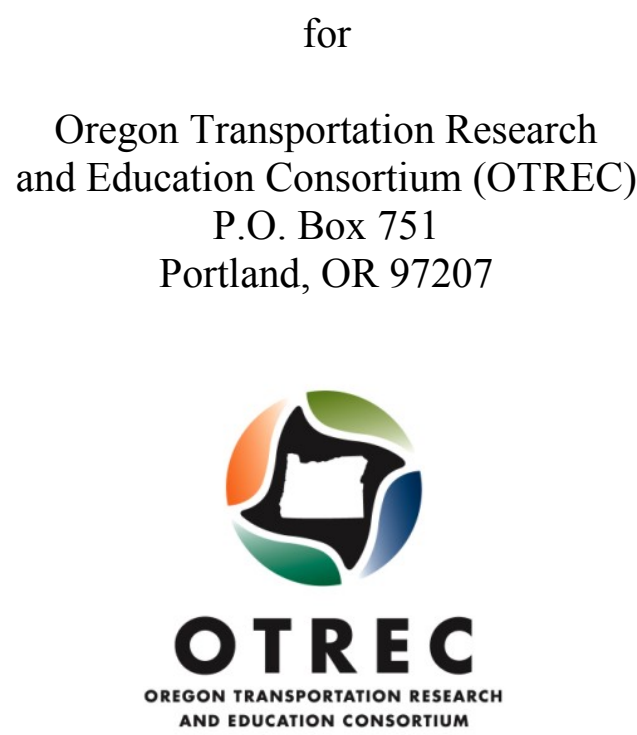

September 2009 



\section{Technical Report Documentation Page}

\begin{tabular}{|l|l|l}
\hline $\begin{array}{l}\text { 1. Report No. } \\
\text { OTREC-RR-09-06 }\end{array}$ & 2. Government Accession No. & \\
\hline
\end{tabular}

\section{Title and Subtitle}

The Built Environment, Neighborhood Safety, and Physical Activity among Low Income Children

\section{Author(s)}

Jessica Greene and Debbie Daniel

9. Performing Organization Name and Address

The University of Oregon

1209 University of Oregon

Eugene, OR 97403-1209

12. Sponsoring Agency Name and Address

Oregon Transportation Research

and Education Consortium (OTREC)

P.O. Box 751

Portland, Oregon 97207

15. Supplementary Notes
3. Recipient's Catalog No.

5. Report Date

September 2009

6. Performing Organization Code

8. Performing Organization Report No.

11. Contract or Grant No.

13. Type of Report and Period Covered

14. Sponsoring Agency Code

\section{Abstract}

There is a growing body of evidence that environmental factors are related to physical activity and active modes of transportation. There is a separate body of research that links neighborhood safety to physical activity. This study used a cross sectional telephone survey of 801 parents/guardians of low income children in Florida to bridge these literatures and examine the independent relationship of the built environment and neighborhood safety on childrens' physical activity.

In multivariate regression models we find that neighborhood safety is a more consistent predictor of low income children's physical activity. In neighborhoods where parents reported that there was a safe outdoor place for children to play, children more frequently engaged in vigorous exercise. Children in these neighborhoods were also more likely to participate in sports teams and classes. Measures of the built environment, in contrast, were not related to physical activity. In sum, our findings point to the potential role of public safety in influencing physical activity. Efforts to improve neighborhood safety may have the added benefit of increasing children's physical activity levels in low income areas.

\section{Key Words}

18. Distribution Statement No restrictions. Copies available from OTREC: www.otrec.us

Physical activity, active transportation, built environment, neighborhood safety

19. Security Classification (of this report)

20. Security Classification (of this page)
Unclassified

21. No. of Pages
22





\section{ACKNOWLEDGEMENTS}

This project was funded by the Oregon Transportation Research and Education Consortium (OTREC) and The Center for Health Care Strategies (CHCS), in Hamilton, N.J. The CHCS grant was made possible through a separate grant to CHCS by the Robert Wood Johnson Foundation.

The authors also would like to acknowledge Lori Quillen for her excellent GIS work on the project.

\section{DISCLAIMER}

The contents of this report reflect the views of the authors, who are solely responsible for the facts and the accuracy of the material and information presented herein. This document is disseminated under the sponsorship of the U.S. Department of Transportation University Transportation Centers Program in the interest of information exchange. The U.S. Government and CHCS assume no liability for the contents or use thereof. The contents do not necessarily reflect the official views of the U.S. Government or CHCS. This report does not constitute a standard, specification, or regulation. 



\section{TABLE OF CONTENTS}

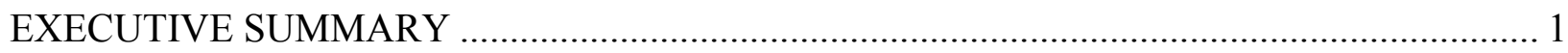

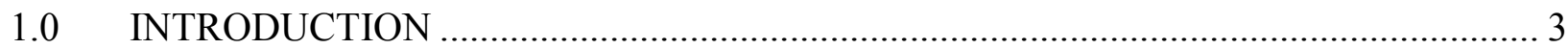

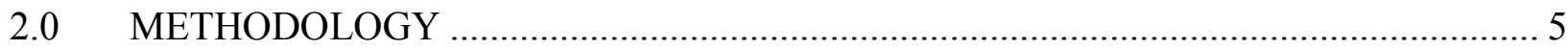

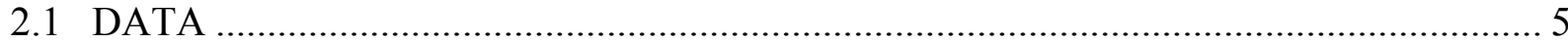

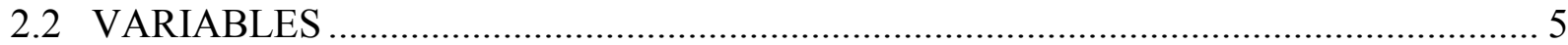

2.2.1 Physical-Activity Measures (Dependent Variables) .............................................. 5

2.2.2 Built-Environment and Neighborhood-Safety Measures (Independent Variables) .... 5

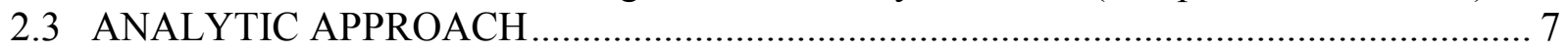

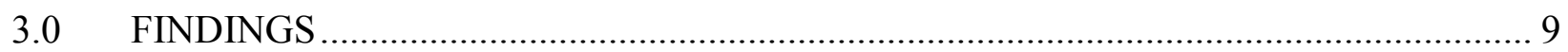

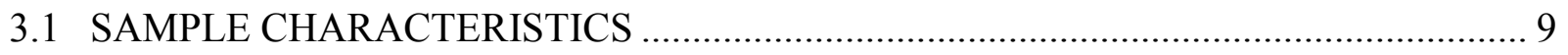

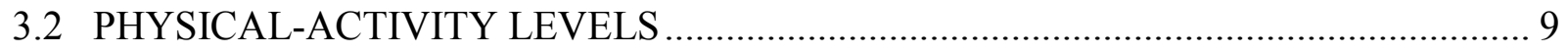

3.3 BIVARIATE RELATIONSHIP BETWEEN BUILT ENVIRONMENT AND

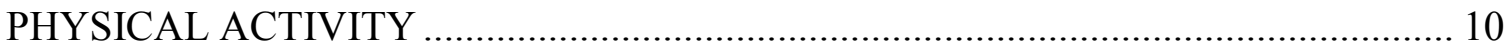

3.4 BIVARIATE RELATIONSHIPS BETWEEN NEIGHBORHOOD SAFETY AND PHYSICAL-ACTIVITY MEASURES …................................................................. 11

3.5 MULTIVARIATE RELATIONSHIPS BETWEEN BUILT ENVIRONMENT, NEIGHBORHOOD SAFETY, AND PHYSICAL ACTIVITY ..................................... 11

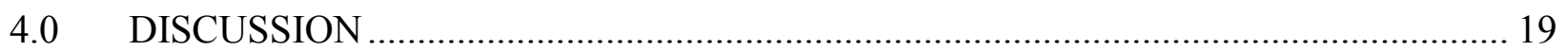

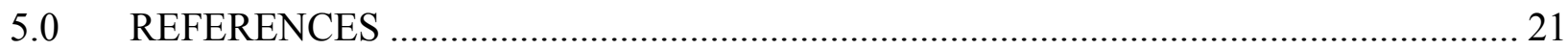

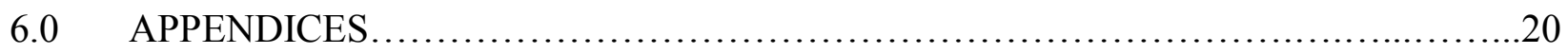




\section{LIST OF TABLES}

Table 2.1 Measures of the Built Environment (at the Zip-Code Level) ................................. 6

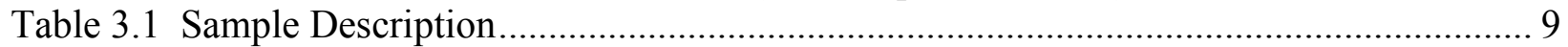

Table 3.2 Physical Activity, by Age and Gender................................................................ 10

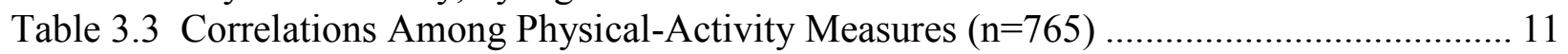

Table 3.4 Correlations Among Key Physical-Activity Measures and Built-Environment

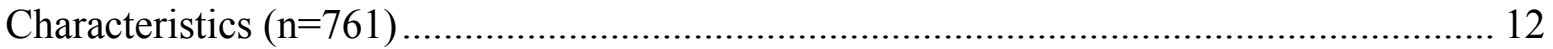

Table 3.5 Correlations Among Key Physical-Activity Measures and Safety Characteristics

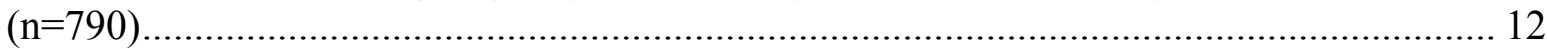

Table 3.6 Multivariate Models Examining Built-Environment and Neighborhood-Safety Predictors of Physical Activity ............................................................................. 15

Table 3.7 Multivariate Models Examining Built-Environment and Neighborhood-Safety Predictors of Physical Activity, By Child's Age .......................................................... 16

Table 3.8 Multivariate Models Examining Built-Environment Predictors of Physical Activity,

By Perceived Neighborhood Safety ......................................................................... 17

Table 6.1 Correlations Among Physical-Activity Measures, Children Ages 5-11 (n=444)....... 23

Table 6.2 Correlations Among Physical-Activity Measures, Children Ages 11-18 $(\mathrm{n}=315) \ldots \ldots .23$

Table 6.3 Correlations Among Physical-Activity Measures, Girls $(\mathrm{n}=413)$............................ 24

Table 6.4 Correlations Among Physical-Activity Measures, Boys $(n=382)$........................... 24 


\section{EXECUTIVE SUMMARY}

There is a growing body of evidence that environmental factors are related to physical activity and active modes of transportation. There is a separate body of research that links neighborhood safety to physical activity. This study used a cross-sectional telephone survey of 801 parents/guardians of low-income children in Florida to bridge these literatures and examine the independent relationship of the built environment and neighborhood safety on childrens' physical activity.

Multivariate regression models suggest that neighborhood safety is a more consistent predictor of low-income children's physical activity. In neighborhoods where parents reported that there was a safe outdoor place for children to play, children more frequently engaged in vigorous exercise. Children in these neighborhoods also were more likely to participate in sports teams and classes. Measures of the built environment, in contrast, were not related to physical activity. In sum, the analysis points to the potential role of public safety in influencing physical activity. Efforts to improve neighborhood safety may have the added benefit of increasing children's physical-activity levels in low-income areas. 


\subsection{INTRODUCTION}

Since the mid-1980s, the prevalence of overweight children in the United States has increased dramatically. Currently, 17\% of children 6-19 years old are overweight, compared with $6 \%$ in the late 1970s (Ogden, Carroll et al. 2006). Low-income and minority children are particularly at risk for obesity (Wang and Beydoun 2007). Obesity in children has been documented as having numerous negative health impacts, including higher rates of hyperlipidemia, hypertension and diabetes (Dietz 1998). In addition, obese children face the challenge of discrimination from their peers. Obese children are far more likely than other children to become obese as adults (Guo, Roche et al. 1994). Obesity now is implicated in approximately $15 \%$ of all deaths, making it the second cause of mortality in the United States (Mokdad, Marks et al. 2004). The Institute of Medicine recently stated that, "Prevention of obesity in children and youth should be a national public health priority" (Koplan, T. Liverman et al. 2004). Obesity prevention among low-income children is particularly important given their disproportionately high rates of obesity.

One of the key determinants of obesity, and an important independent indicator of health, is physical activity. For children, a key component of physical activity is active transportation to and from school. Walking to school has been shown to be a strong predictor of overall physicalactivity levels among older children (Alexander, Inchley et al. 2005; Cooper, Page et al. 2003). Between 1977 and 2001, however, the percent of children's school trips that involved walking declined precipitously, from $20 \%$ to $12 \%$ (Sturm 2005).

While individuals make choices regarding whether or not to engage in physical activity, researchers have started documenting that community-level or environmental factors are associated with physical activity and active transportation. There is strong evidence that the built environment is related to physical activity and active modes of transportation (Committee on Physical Activity 2005; Ewing 2005; Ewing, Schmid et al. 2003; Kelly-Schwartz, Stockard et al. 2004). Residents of neighborhoods that are more "walkable" - that is, with more intersections, fewer dead-ends, and smaller street-block sizes - are more likely to be physically active. Studies of children also have found that walkability or built-environment factors such as intersection density, population density, and tree cover near schools are positive predictors of walking to school (Braza, Shoemaker et al. 2004; McMillan 2003; Schlossberg, Greene et al. 2006).

Other investigators have found that neighborhood safety is positively related to levels of physical activity (Molnar, Gortmaker et al. 2004; Trost, Owen et al. 2002). Only a few studies have bridged these two literatures and examined the independent contributions of neighborhood safety and the built environment on physical activity (Brownson, Baker et al. 2001; Doyle, KellySchwartz et al. 2006). These studies, which have been conducted with adults, have found that both "walkability" and neighborhood safety are independent predictors of physical activity, and that neighborhood safety particularly influences women's physical-activity levels.

In this study we add to the literature by examining the independent influences of the built environment and neighborhood safety on physical activity among low-income children. While the literature on environmental influences on physical activity has grown dramatically in recent 
years, little of the research has focused on low-income and minority children (Day and Cardinal 2007). Since low-income children are more likely to live in areas with high crime rates and unsafe traffic, and they are more likely to have high rates of obesity, it is important to identify the independent influence of the built environment and safety on physical activity. Policymakers then can target the most appropriate interventions to improve health for this vulnerable population.

Further, the study examines whether the built environment is as important a predictor of physical activity for children living in less-safe neighborhoods compared to those living in safer neighborhoods. The studyhypothesis is that a minimal level of neighborhood safety is necessary for the built-environment factors to influence physical activity among low-income children. 


\subsection{METHODOLOGY}

\subsection{DATA}

The data for this study comes from a cross-sectional telephone survey of 801 parents and guardians of low-income children in Florida. The survey was conducted in the fall of 2006 in four counties (Broward, Duval, Escambia, and Palm Beach). The survey, which was designed to explore healthy behaviors of children with Medicaid, covered topics including physical activity, neighborhood safety, and demographics.

Sampling for the survey was based upon Medicaid program eligibility. The Medicaid program provides health coverage to over 55 million low-income people in the Unite States. Children's parents or guardians were eligible to participate in the survey if their child was aged 4-18 and had participated in the Medicaid program for at least three months. The response rate was $44 \%$.

\subsection{VARIABLES}

\subsubsection{Physical-Activity Measures (Dependent Variables)}

Prior research has found that different types of physical activity are related to different environmental factors (Lee 2007). Therefore, we examined several different physical-activity measures in this study. First was a measure of active transportation to school. Respondents were asked, "During the school year, does [child's name] regularly walk or bike to school?" This was asked only if the child was school aged ( 5 years or older).

The second physical-activity item, which is from the National Health and Nutrition Examination Survey (NHANES), measured the frequency of vigorous exercise. Respondents were asked, "How many times per week does [CHILD] play or exercise enough to make [him/her] sweat and breath hard [like playing basketball or running]?" A similar item measured the frequency of walking: "How many days in the last week did [CHILD $\}$ walk for 10 or more minutes?" This item was adapted from Brownson and colleagues (2004).

The final item came from the National Survey of Children's Health. It asked, "During the past 12 months, was [CHILD] on a sports team or did [he/she] take sports lessons?"

\subsubsection{Built-Environment and Neighborhood-Safety Measures (Independent Variables)}

The independent variables related either to the built environment or neighborhood safety. We used five built-environment measures that have been used in prior studies of active transportation 
and physical activity: the ratio of major to minor roads, intersection density, dead-end density, residential density, land-use mix, and percent recreational land. Each were developed at the zipcode level using Geographic Information Systems (survey respondents provided their zip code). On average, the zip codes where our sample resided were one-half square miles. The definition of the measures along with data sources and descriptives are provided in Table 1.

Table 2.1 Measures of the Built Environment (at the Zip-Code Level)

\begin{tabular}{|c|c|c|c|c|}
\hline & Definition & Data Source & Mean & $\begin{array}{l}\text { Standard } \\
\text { Deviation }\end{array}$ \\
\hline Land-Use Mix & $\begin{array}{l}\text { Evenness of } \\
\text { distribution of square } \\
\text { footage of residential, } \\
\text { commercial, and office } \\
\text { development* }\end{array}$ & $\begin{array}{l}\text { Florida Department of } \\
\text { Transportation (DOT) } \\
\text { Parcel Land-Use } \\
\text { Data(2000) }\end{array}$ & 0.6 & 0.2 \\
\hline $\begin{array}{l}\text { Percent } \\
\text { Recreational Land } \\
\text { in Zip Code }\end{array}$ & $\begin{array}{l}\text { Percent of the land in } \\
\text { the zip code that is } \\
\text { recreational }\end{array}$ & $\begin{array}{l}\text { Florida D.O.T. Parcel } \\
\text { Land-Use Data(2000) }\end{array}$ & 0.1 & 0.1 \\
\hline $\begin{array}{l}\text { Ratio of Major to } \\
\text { Minor Roads }\end{array}$ & $\begin{array}{l}\text { The ratio of major } \\
\text { arterials to minor roads }\end{array}$ & $\begin{array}{l}\text { Street and zip code } \\
\text { Tiger Data from ESRI } \\
(2000)\end{array}$ & 0.1 & 0.1 \\
\hline $\begin{array}{l}\text { Intersection } \\
\text { Density }\end{array}$ & $\begin{array}{l}\text { Number of 3-, 4- and 5- } \\
\text { way intersections per } \\
\text { square mile }\end{array}$ & $\begin{array}{l}\text { Street and zip code } \\
\text { Tiger Data from ESRI } \\
(2000)\end{array}$ & 81.0 & 42.8 \\
\hline Dead-end Density & $\begin{array}{l}\text { Number of dead-ends } \\
\text { per square mile }\end{array}$ & $\begin{array}{l}\text { Street and zip code } \\
\text { Tiger Data from ESRI } \\
(2000)\end{array}$ & 17.5 & 7.7 \\
\hline $\begin{array}{l}\text { Residential } \\
\text { Density }\end{array}$ & $\begin{array}{l}\text { Number of housing } \\
\text { units per square mile }\end{array}$ & 2000 U.S. Census Data & 771.8 & 703.9 \\
\hline
\end{tabular}

The perceived level of neighborhood safety was measured using the following items, adapted from Brownson and colleagues (2004): "There is a safe, outdoor place for children to play outside my home"; "It is not safe to go on walks during the day in the neighborhood"; and "The playgrounds in the neighborhood are safe and well-maintained." Respondents were asked how true each statement was: "very true," "somewhat true" or "not true." Perceived measures of safety were used for two reasons. First, it has been argued that physical-activity behavior would be more influenced by how individuals perceive their neighborhoods' safety than an absolute safety measure. Second, objective crime data collected by the FBI is only available at the city level and not at the zip-code level. Therefore, data was unavailable from each individual precinct. 


\subsection{ANALYTIC APPROACH}

After examining the basic demographics of the sample, the physical-activity behaviors were examined by childrens' gender and age. Given interest in the extent to which active transportation to school is related to other physical-activity measures, the correlations among all four physical-activity measures were examined. Since prior studies have found that these relationships may depend on the age and gender of children (Cooper, Page et al. 2003; Metcalf, Voss L et al. 2004), separate analyses by age and gender were conducted.

Next, correlations among the independent variables and the physical-activity measures were examined. First the correlation matrix for physical activity and the built-environment factors were examined, and then for physical activity and neighborhood safety.

Multivariate models were then conducted that included those built-environment and safety items that exhibited a significant relationship with at least one of the physical-activity measures in bivariate analyses. These models, which examined the independent influences of the built environment and safety, controlled for children's individual characteristics (gender, age, race/ethnicity, and health status) and parent/guardian's characteristics (gender, educational attainment, and household having a car). All regression models adjusted for the clustering of the built-environment measures at the zip-code level. Tests for multicollearity suggested that the independent variables were not highly correlated.

The type of multivariate regression used in the analyses depended upon the form of the dependent variable. For active transportation and participation in a sports team or class, both of which were dichotomous, logistic regression was used. For vigorous exercise or walking 10 or more minutes, poisson models were used. Poisson models are appropriate for count data when there is no indication of overdispersion (Allison 1991), as was the case for these variables.

Separate analyses were conducted based upon the age of the child, separating young children (aged 4-11) from adolescents (aged 12-18). To examine whether the built-environment factors were equally as important in safer and less-safe neighborhoods, a measure of neighborhood safety was created. If a respondent said it was "not true" that "there is a safe, outdoor place for kids to play outside" or if he or she said it was "somewhat" or "very" true that "it is not safe to walk during the day in the neighborhood," then the neighborhood was considered not safe. Due to the lack of relationship between the built environment and participation in sports teams or classes in preliminary analyses, and because of space constraints, stratified analyses for that variable were not conducted. 


\subsection{FINDINGS}

\subsection{SAMPLE CHARACTERISTICS}

The sample of Medicaid recipients is of low socioeconomic status, which is consistent with Medicaid income eligibility requirements. The respondents (parents or guardians of the children) had relatively low levels of educational attainment. A quarter did not graduate from high school (Table 3.1), compared to $15 \%$ of adults nationally (US Census Bureau 2008). Twenty-two percent had no car in the household, which is over twice the national level (Hu and Reuscher 2004). Only half (56\%) had a bank account that they could withdraw money from.

The children were from diverse racial and ethnic backgrounds. Over half (57\%) were African-American and $12 \%$ were Latino. Only $23 \%$ were white. They were equally divided by gender, though the survey respondents were overwhelmingly female $(92 \%)$. The children's ages ranged from 4 to 18 years old, with children under 12 making up the bulk of the sample $(60 \%)$.

Approximately 70\% were reported to be in "excellent" or "very good" health. While this percentage is similar to national data on children with Medicaid coverage, it is considerably lower than the norm for children nationwide (82\%) (Bloom B and RA 2007).

\subsection{PHYSICAL-ACTIVITY LEVELS}

The children in the sample engaged in vigorous exercise five days a week on average (Table 3.2). This level was high compared to national data on children in the United States. In this survey 39\% were reported to exercise vigorously every day, compared to only $26 \%$ in a national survey of children (U.S. Department of Health and Human Resources 2003). The children also took walks of 10 minutes or longer five days a week on average.
Table 3.1 Sample Description

\begin{tabular}{|c|c|}
\hline & $\begin{array}{c}\text { Percent of } \\
\text { Sample } \\
(\mathrm{n}=801)\end{array}$ \\
\hline \multicolumn{2}{|l|}{ Child's Characteristics } \\
\hline \multicolumn{2}{|l|}{ Gender } \\
\hline Boy & 47.9 \\
\hline Girl & 52.1 \\
\hline \multicolumn{2}{|l|}{ Age } \\
\hline $4-7$ & 31.6 \\
\hline $8-11$ & 28.6 \\
\hline $12-18$ & 39.8 \\
\hline \multicolumn{2}{|l|}{ Race/ethnicity } \\
\hline African-American & 57.8 \\
\hline White & 23.3 \\
\hline Latino & 12.1 \\
\hline Other & 6.8 \\
\hline \multicolumn{2}{|l|}{ Child's Health Status } \\
\hline Excellent & 39.8 \\
\hline Very good & 31.3 \\
\hline Good & 20.7 \\
\hline Fair or Poor & 8.1 \\
\hline \multicolumn{2}{|l|}{$\begin{array}{l}\text { Parent/Guardian } \\
\text { Characteristics }\end{array}$} \\
\hline \multicolumn{2}{|l|}{ Gender } \\
\hline Male & 8.4 \\
\hline Female & 91.6 \\
\hline \multicolumn{2}{|l|}{ Educational Attainment } \\
\hline $\begin{array}{l}\text { Did not graduate from high } \\
\text { school }\end{array}$ & 24.6 \\
\hline Graduated from high school & 39.2 \\
\hline $\begin{array}{l}\text { Attended at least some } \\
\text { college }\end{array}$ & 36.2 \\
\hline \multicolumn{2}{|l|}{$\begin{array}{l}\text { Have bank account with } \\
\text { money to withdraw }\end{array}$} \\
\hline Yes & 56.3 \\
\hline No & 43.7 \\
\hline \multicolumn{2}{|l|}{ Household has car } \\
\hline Yes & 78.0 \\
\hline No & 22.0 \\
\hline
\end{tabular}


Thirty-two percent of children regularly walked or biked to school. Almost half (47\%) participated in sports teams or classes in the past year, which was 10 percentage points lower than data for children nationally (U.S. Department of Health and Human Resources 2003).

Table 3.2 Physical Activity, by Age and Gender

\begin{tabular}{|c|c|c|c|c|c|}
\hline \multirow[b]{2}{*}{ Physical Activity } & \multirow[b]{2}{*}{$\begin{array}{c}\text { Total } \\
\text { Sample } \\
(\mathrm{n}=801)\end{array}$} & \multicolumn{4}{|c|}{ Age \& Gender } \\
\hline & & $\begin{array}{c}\text { Boys } \\
4-11 \\
\text { Years } \\
(n=233)\end{array}$ & $\begin{array}{c}\text { Girls } \\
4-11 \\
\text { Years } \\
(n=249)\end{array}$ & $\begin{array}{c}\text { Boys } \\
12-18 \\
\text { Years } \\
(\mathrm{n}=151)\end{array}$ & $\begin{array}{c}\text { Girls } \\
12-18 \\
\text { Years } \\
(\mathrm{n}=168)\end{array}$ \\
\hline $\begin{array}{l}\text { Regularly Walks or Bikes to } \\
\text { School (\%) }\end{array}$ & 31.7 & 31.0 & 29.8 & 32.4 & 34.3 \\
\hline $\begin{array}{l}\text { Days per Week Walking } 10 \\
\text { or More Minutes (mean) }\end{array}$ & 5.0 & 5.2 & 4.7 & 5.3 & $5.1 * * *$ \\
\hline $\begin{array}{l}\text { Days per Week Vigorous } \\
\text { Exercise (mean) }\end{array}$ & 5.2 & 5.5 & 5.3 & 5.1 & $4.6 * * *$ \\
\hline $\begin{array}{l}\text { Participates in Sports Teams } \\
\text { or Classes }(\%)\end{array}$ & 47.2 & 40.3 & 39.8 & 62.3 & $53.9^{* * *}$ \\
\hline
\end{tabular}

Adolescent girls participated in vigorous exercise less frequently than boys or younger girls (Table 3.2). Younger girls (aged 4-11) had lower levels of walking compared with boys and adolescent girls. Younger children, regardless of gender, were less likely to participate in a sports team or class than were adolescents. Among adolescents, however, girls were less likely to participate in teams/classes than boys ( $54 \%$ versus $62 \%)$.

Table 3.3 presents the correlations among the physical-activity measures for children 5 years old and older. Walking or biking to school was positively correlated with walking 10 or more minutes per day $(\mathrm{r}=.11)$, which in turn was positively correlated to frequency of vigorous exercise $(\mathrm{r}=.31)$. Participating in a team sport or class was not related to the other three physicalactivity measures.

In additional analyses, these correlations were examined to see whether they were consistent for younger and older children, and for boys and girls (Appendix Tables 6.1-6.4). These analyses suggest that active transportation is predictive of more frequent walking among younger children and among girls, but not among older children or boys. The relationship between walking and vigorous exercise was consistent regardless of a child's age or gender.

\subsection{BIVARIATE RELATIONSHIP BETWEEN BUILT ENVIRONMENT AND PHYSICAL ACTIVITY}

Four of the built-environment characteristics were related to the physical-activity measures (Table 3.4). Children were less likely to walk or bike to school in zip codes where there were more major roads relative to minor roads $(\mathrm{r}=-.09)$. However, counter to expectations, the analyses shows that children more frequently exercised vigorously and walked in areas where there were more major roads. In zip codes with higher intersection density, there was more active transportation to schools $(\mathrm{r}=.13)$, and where there were more dead-ends there was less 
frequent walking $(\mathrm{r}=-.11)$. Residential density was negatively related to the frequency of vigorous exercise $(\mathrm{r}=-.08)$. There was no relationships between the physical-activity measures and land-use mix or the percent of recreational land in the zip code.

Table 3.3 Correlations Among Physical-Activity Measures (n=765)

\begin{tabular}{l|c|c|c|c}
\hline & $\begin{array}{c}\text { Regularly } \\
\text { Walks or Bikes } \\
\text { to School }\end{array}$ & $\begin{array}{c}\text { Days per Week } \\
\text { Walking 10 or } \\
\text { More Minutes }\end{array}$ & $\begin{array}{c}\text { Days per Week } \\
\text { Vigorous } \\
\text { Exercise }\end{array}$ & $\begin{array}{c}\text { Participates in } \\
\text { Sports Teams } \\
\text { or Exercise or } \\
\text { Classes }\end{array}$ \\
\hline $\begin{array}{l}\text { Regularly Walks or Bikes to } \\
\text { School }\end{array}$ & 1.00 & $0.11^{* *}$ & 0.04 & 0.00 \\
\hline $\begin{array}{l}\text { Days per Week Walking 10 } \\
\text { or More Minutes }\end{array}$ & 1.00 & $0.31^{* *}$ & 0.05 \\
\hline $\begin{array}{l}\text { Days per Week Vigorous } \\
\text { Exercise }\end{array}$ & & 1.00 & 0.04 \\
\hline $\begin{array}{l}\text { Participates in Sports Teams } \\
\text { or Classes }\end{array}$ & & & & 1.00 \\
\hline
\end{tabular}

$* \mathrm{p}<.05 * * \mathrm{p}<.01$

Note: Only children 5 and older are included since younger children do not necessarily attend school.

\subsection{BIVARIATE RELATIONSHIPS BETWEEN NEIGHBORHOOD SAFETY AND PHYSICAL-ACTIVITY MEASURES}

Respondents on the whole did not feel that their neighborhoods were very safe for children. Fewer than half reported that it was "very true" that there was "a safe, outdoor place to play" $(41 \%)$ or that "neighborhood playgrounds are safe and well-maintained" (45\%). Fifteen percent said it was "very true" that "it is not safe to go on walks by day in the neighborhood."

Two of the safety items were significantly related to children's physical activity (Table 3.5). In neighborhoods where there were safe, outdoor places to play, children more frequently engaged in vigorous exercise and walking, and they were more likely to have participated in a sports team or class in the prior year. Counter to expectations, in neighborhoods where it was safe to go on walks during the day, children were less likely to regularly walk or bike to school compared to neighborhoods where it was not considered safe.

\subsection{MULTIVARIATE RELATIONSHIPS BETWEEN BUILT ENVIRONMENT, NEIGHBORHOOD SAFETY, AND PHYSICAL ACTIVITY}

In multivariate models that control for child and parent/guardian characteristics, the builtenvironment factors were no longer significant predictors of the physical-activity 
Table 3.4 Correlations Among Key Physical-Activity Measures and Built-Environment Characteristics (n=761)

\begin{tabular}{|c|c|c|c|c|c|c|c|c|c|c|}
\hline & $\begin{array}{c}\text { Regularly } \\
\text { Walks or } \\
\text { Bikes to } \\
\text { School }\end{array}$ & $\begin{array}{l}\text { Days per } \\
\text { Week } \\
\text { Vigorous } \\
\text { Exercise }\end{array}$ & $\begin{array}{c}\text { Days per } \\
\text { Week } \\
\text { Walking }\end{array}$ & $\begin{array}{c}\text { Partic- } \\
\text { ipates } \\
\text { in } \\
\text { Team/ } \\
\text { Class }\end{array}$ & $\begin{array}{l}\text { Land } \\
\text {-Use } \\
\text { Mix }\end{array}$ & $\begin{array}{c}\text { Percent } \\
\text { Recrea- } \\
\text { tional } \\
\text { Land }\end{array}$ & $\begin{array}{c}\text { Ratio of } \\
\text { Major to } \\
\text { Minor } \\
\text { Roads }\end{array}$ & $\begin{array}{c}\text { Intersec- } \\
\text { tion } \\
\text { Density }\end{array}$ & $\begin{array}{l}\text { Dead- } \\
\text { end } \\
\text { Densi } \\
\text { ty }\end{array}$ & $\begin{array}{c}\text { Residen- } \\
\text { tial } \\
\text { Density }\end{array}$ \\
\hline $\begin{array}{l}\text { Regularly } \\
\text { Walks or } \\
\text { Bikes to } \\
\text { School }\end{array}$ & 1.00 & 0.04 & $0.11 * *$ & 0.00 & 0.07 & 0.06 & $-0.09 *$ & $0.13^{* * *}$ & 0.07 & 0.02 \\
\hline $\begin{array}{l}\text { Days per } \\
\text { Week } \\
\text { Vigorous } \\
\text { Exercise }\end{array}$ & & 1.00 & $0.32 * * *$ & 0.03 & 0.02 & 0.04 & $0.08^{*}$ & 0.01 & -0.01 & $-0.08^{*}$ \\
\hline $\begin{array}{l}\text { Days per } \\
\text { Week } \\
\text { Walking }\end{array}$ & & & 1.00 & 0.06 & 0.02 & 0.02 & $0.09 *$ & 0.00 & $\begin{array}{l}- \\
0.11 * \\
*\end{array}$ & 0.06 \\
\hline $\begin{array}{l}\text { Partici- } \\
\text { pates in } \\
\text { Team or } \\
\text { Class }\end{array}$ & & & & 1.00 & -0.04 & 0.06 & -0.06 & 0.01 & 0.04 & -0.00 \\
\hline $\begin{array}{l}\text { Land-Use } \\
\text { Mix }\end{array}$ & & & & & 1.00 & $0.13 * *$ & $0.08 * *$ & $0.24 * * *$ & $0.08^{*}$ & $0.09^{*}$ \\
\hline $\begin{array}{l}\text { Percent } \\
\text { Recreation } \\
\text { al Land in } \\
\text { Zip Code }\end{array}$ & & & & & & 1.00 & $-0.11 * * *$ & $0.10^{* * *}$ & $\begin{array}{l}0.19 * \\
* *\end{array}$ & $0.16^{* * *}$ \\
\hline $\begin{array}{l}\text { Ratio of } \\
\text { Major/ } \\
\text { Minor } \\
\text { Roads }\end{array}$ & & & & & & & 1.00 & $-0.35 * * *$ & $\begin{array}{l}- \\
0.50 * \\
* *\end{array}$ & $-0.09 *$ \\
\hline $\begin{array}{l}\text { Intersect- } \\
\text { ion } \\
\text { Density }\end{array}$ & & & & & & & & 1.00 & $\begin{array}{l}0.40 * \\
* *\end{array}$ & $0.28 * * *$ \\
\hline $\begin{array}{l}\text { Dead-end } \\
\text { Density }\end{array}$ & & & & & & & & & 1.00 & 0.04 \\
\hline $\begin{array}{l}\text { Residen- } \\
\text { tial } \\
\text { Density }\end{array}$ & & & & & & & & & & 1.00 \\
\hline
\end{tabular}

$* \mathrm{p}<.05 * * \mathrm{p}<.01 * * * \mathrm{p}<.001$

Table 3.5 Correlations Among Key Physical-Activity Measures and Safety Characteristics (n=790) 


\begin{tabular}{|c|c|c|c|c|c|c|c|}
\hline & $\begin{array}{c}\text { Regularly } \\
\text { Walks or } \\
\text { Bikes to } \\
\text { School }\end{array}$ & $\begin{array}{l}\text { Days per } \\
\text { Week } \\
\text { Vigorous } \\
\text { Exercise }\end{array}$ & $\begin{array}{l}\text { Days per } \\
\text { Week } \\
\text { Walking }\end{array}$ & $\begin{array}{l}\text { Participates } \\
\text { in Sports } \\
\text { Team/Class }\end{array}$ & $\begin{array}{c}\text { Safe, } \\
\text { Outdoor } \\
\text { Place to Play }\end{array}$ & $\begin{array}{l}\text { Playgrounds } \\
\text { are Safe }\end{array}$ & $\begin{array}{c}\text { Not Safe to } \\
\text { Go on Walks } \\
\text { by Day }\end{array}$ \\
\hline $\begin{array}{l}\text { Regularly } \\
\text { Walks or } \\
\text { Bikes to } \\
\text { School }\end{array}$ & 1.00 & 0.04 & $0.11^{*}$ & 0.00 & -0.01 & 0.04 & $0.08^{*}$ \\
\hline $\begin{array}{l}\text { Days per } \\
\text { Week } \\
\text { Vigorous } \\
\text { Exercise }\end{array}$ & & 1.00 & $0.32 * * *$ & 0.03 & $0.10 * *$ & 0.05 & -0.05 \\
\hline $\begin{array}{l}\text { Days per } \\
\text { Week } \\
\text { Walking }\end{array}$ & & & 1.00 & 0.06 & $0.09 *$ & 0.06 & -0.05 \\
\hline $\begin{array}{l}\text { Participates } \\
\text { in Sports } \\
\text { Team/Class }\end{array}$ & & & & 1.00 & $0.08^{*}$ & 0.04 & -0.04 \\
\hline $\begin{array}{l}\text { Safe, } \\
\text { Outdoor } \\
\text { Place to } \\
\text { Play }\end{array}$ & & & & & 1.00 & $0.46^{* * *}$ & $-0.19 * *$ \\
\hline $\begin{array}{l}\text { Play- } \\
\text { grounds are } \\
\text { Safe }\end{array}$ & & & & & & 1.00 & $-0.14 * * *$ \\
\hline $\begin{array}{l}\text { Not Safe to } \\
\text { Go on } \\
\text { Walks by } \\
\text { Day }\end{array}$ & & & & & & & 1.00 \\
\hline
\end{tabular}

${ }^{*} \mathrm{p}<.05 * * \mathrm{p}<.01 * * * \mathrm{p}<.001$

Note: Scale on the safety items was $1=$ not true, $2=$ somewhat true, $3=$ very true

measures (Table 3.6). Additional models were run that examined active transportation among the subset of children who were elementary aged and who lived within a 15 minute walk of an elementary school. These models found that the built-environment factors were not predictive of active transportation (Appendix Table 6.5).

One neighborhood-safety measure maintained significant relationships with the physical-activity measures. Having a safe, outdoor place for children to play continued to be a positive predictor of the frequency of vigorous exercise and for participation in a sports team or class. However, it was no longer predictive of the frequency of walking.

The models confirmed prior studies' findings that girls are less physically active than boys, that the frequency of vigorous exercise is lower among older than younger children, and children in better health are more physically active. Also, not having a car in the household was a strong predictor of active transportation to school and more frequent walking.

We found that African-American children were more likely than whites to walk or bike to school, and Latinos engaged in vigorous exercise less frequently than whites. 
Table 3.7 presents the multivariate models stratified by age group. For younger children (4-11 year olds) residential density was positively associated with frequency of walking. None of the other built-environment or safety measures were associated. For older children (12-18 year olds) dead-end density was negatively associated with the frequency of walking and residential density had a negative relationship with frequency of vigorous exercise. As in the bivariate models, in neighborhoods considered not safe, children walked less frequently.

To examine the hypothesis that the built environment would be more strongly associated with physical activity in neighborhoods that were considered safe, the analysis was stratified by neighborhood safety. Table 3.8 presents thefindings, which do not support the hypothesis. In the safer neighborhoods, none of the built-environment factors were predictive of physical activity. In the less-safe neighborhoods, however, two significant relationships that were consistent with the bivariate findings in Table 3.4 were observed. Intersection density was positively related to active transportation to school. Also, in neighborhoods with more major roads relative to minor roads, children more frequently engaged in vigorous exercise. 
Table 3.6 Multivariate Models Examining Built-Environment and Neighborhood-Safety Predictors of Physical Activity

\begin{tabular}{|c|c|c|c|c|}
\hline & $\begin{array}{l}\text { Regularly Walks } \\
\text { or Bikes to School } \\
\text { (n=704) } \\
\text { (Odds Ratios) }\end{array}$ & $\begin{array}{c}\text { Participated in } \\
\text { Sports Team/Class } \\
\text { in Prior Year } \\
(\mathrm{n}=704) \\
\text { (Odds Ratios) }\end{array}$ & $\begin{array}{c}\text { Days per Week } \\
\text { Vigorous Exercise } \\
(\mathrm{n}=735) \\
\text { (Poisson } \\
\text { Coefficients) }\end{array}$ & $\begin{array}{l}\text { Days per Week } \\
\text { Walking } \\
(\mathrm{n}=724) \\
\text { (Poisson } \\
\text { Coefficients) }\end{array}$ \\
\hline \multicolumn{5}{|l|}{ Built Environment } \\
\hline $\begin{array}{l}\text { Ratio of Major/Minor } \\
\text { Roads }\end{array}$ & 0.04 & 0.29 & 0.40 & 0.21 \\
\hline Intersection Density & 1.00 & 1.00 & 0.00 & 0.00 \\
\hline Dead-end Density & 1.02 & 1.01 & 0.00 & 0.00 \\
\hline Residential Density & 1.00 & 1.00 & 0.00 & 0.00 \\
\hline \multicolumn{5}{|l|}{ Safety } \\
\hline $\begin{array}{l}\text { Safe, outdoor place to } \\
\text { play }\end{array}$ & 1.13 & $1.23 *$ & $0.03 *$ & 0.02 \\
\hline $\begin{array}{l}\text { Not safe to go on walks } \\
\text { during the day }\end{array}$ & 1.20 & 0.93 & -0.01 & -0.02 \\
\hline \multicolumn{5}{|l|}{ Child's Characteristics } \\
\hline \multicolumn{5}{|l|}{ Gender } \\
\hline Boy & $(1.00)$ & $(1.00)$ & $(1.00)$ & $(1.00)$ \\
\hline Girl & 1.01 & 0.33 & $-0.09 * * *$ & $-0.07 *$ \\
\hline \multicolumn{5}{|l|}{ Age } \\
\hline $4-7$ & $(1.00)$ & $(1.00)$ & $(1.00)$ & $(1.00)$ \\
\hline $8-11$ & $1.63^{*}$ & $2.18^{* * *}$ & $-0.13 * * *$ & -0.03 \\
\hline $12-18$ & 1.26 & $3.30^{* * *}$ & $-0.18 * * *$ & 0.02 \\
\hline \multicolumn{5}{|l|}{ Race/ethnicity } \\
\hline African-American & $1.73^{*}$ & 1.33 & 0.06 & 0.08 \\
\hline White & $(1.00)$ & $(1.00)$ & $(1.00)$ & $(1.00)$ \\
\hline Latino & 0.91 & 1.03 & $-0.11 *$ & -0.04 \\
\hline Other & 1.19 & 1.95 & 0.03 & 0.06 \\
\hline \multicolumn{5}{|l|}{ Child's Health Status } \\
\hline Excellent & 0.91 & 1.37 & $0.20 *$ & $0.20 *$ \\
\hline Very good & 0.75 & 1.41 & $0.17 *$ & $0.16^{*}$ \\
\hline Good & 0.83 & 0.78 & 0.07 & 0.09 \\
\hline Fair or Poor & $(1.00)$ & $(1.00)$ & $(1.00)$ & $(1.00)$ \\
\hline \multicolumn{5}{|l|}{$\begin{array}{l}\text { Parent/Guardian } \\
\text { Characteristics }\end{array}$} \\
\hline \multicolumn{5}{|l|}{ Gender } \\
\hline Male & $(1.00)$ & $(1.00)$ & $(1.00)$ & $(1.00)$ \\
\hline Female & 0.56 & 0.96 & 0.00 & -0.05 \\
\hline \multicolumn{5}{|l|}{ Educational Attainment } \\
\hline $\begin{array}{l}\text { Did not graduate from } \\
\text { high school }\end{array}$ & 1.46 & $0.56 * *$ & 0.03 & 0.07 \\
\hline $\begin{array}{l}\text { Graduated from high } \\
\text { school }\end{array}$ & $1.53 *$ & $0.59^{*}$ & 0.00 & 0.01 \\
\hline $\begin{array}{l}\text { Attended at least some } \\
\text { college }\end{array}$ & $(1.00)$ & $(1.00)$ & $(1.00)$ & $(1.00)$ \\
\hline \multicolumn{5}{|l|}{ Household has car } \\
\hline Yes & $0.50 * *$ & 1.23 & -0.05 & $-0.08 *$ \\
\hline No & $(1.00)$ & $(1.00)$ & $(1.00)$ & $(1.00)$ \\
\hline
\end{tabular}


Table 3.7 Multivariate Models Examining Built-Environment and Neighborhood-Safety Predictors of Physical Activity, By Child's Age

\begin{tabular}{|c|c|c|c|c|c|c|}
\hline & \multicolumn{2}{|c|}{$\begin{array}{c}\text { Regularly Walks or } \\
\text { Bikes to School } \\
\text { (Odds Ratios) }\end{array}$} & \multicolumn{2}{|c|}{$\begin{array}{c}\text { Days per Week } \\
\text { Vigorous Exercise } \\
\text { (Poisson Coefficient) }\end{array}$} & \multicolumn{2}{|c|}{$\begin{array}{c}\text { Days per Week } \\
\text { Walking } \\
\text { (Poisson Coefficient) }\end{array}$} \\
\hline & $\begin{array}{c}5-11 \text { years } \\
\text { old } \\
(\mathrm{n}=409)\end{array}$ & $\begin{array}{c}12-18 \\
\text { years old } \\
(\mathrm{n}=295)\end{array}$ & $\begin{array}{c}4-11 \text { years } \\
\text { old } \\
(\mathrm{n}=440)\end{array}$ & $\begin{array}{c}12-18 \\
\text { years old } \\
(\mathrm{n}=295)\end{array}$ & $\begin{array}{c}4-11 \text { years } \\
\text { old } \\
(\mathrm{n}=430)\end{array}$ & $\begin{array}{c}12-18 \\
\text { years old } \\
(\mathrm{n}=294)\end{array}$ \\
\hline \multicolumn{7}{|l|}{ Built Environment } \\
\hline $\begin{array}{l}\text { Ratio of Major/Minor } \\
\text { Roads }\end{array}$ & 0.02 & 0.04 & 0.60 & 0.37 & 0.52 & -0.07 \\
\hline Intersection Density & 1.00 & 1.00 & 0.00 & 0.00 & -0.00 & 0.00 \\
\hline Dead-end Density & 1.01 & 1.01 & 0.01 & -0.00 & 0.00 & $-0.01 * *$ \\
\hline Residential Density & 1.00 & 1.00 & 0.00 & $-0.00 * *$ & $0.01 *$ & -0.00 \\
\hline \multicolumn{7}{|l|}{ Safety } \\
\hline $\begin{array}{l}\text { Safe, outdoor place to } \\
\text { play }\end{array}$ & 1.19 & 1.06 & 0.03 & 0.03 & 0.04 & 0.01 \\
\hline $\begin{array}{l}\text { Not safe to go on walks } \\
\text { during the day }\end{array}$ & 1.04 & 1.34 & -0.01 & -0.00 & 0.00 & $-0.06^{*}$ \\
\hline \multicolumn{7}{|l|}{ Child's Characteristics } \\
\hline \multicolumn{7}{|l|}{ Gender } \\
\hline Boy & $(1.00)$ & $(1.00)$ & $(1.00)$ & $(1.00)$ & $(1.00)$ & $(1.00)$ \\
\hline Girl & 1.03 & 1.03 & -0.07 & $-0.12 * *$ & $-0.13 * *$ & 0.01 \\
\hline \multicolumn{7}{|l|}{ Age } \\
\hline $4-7$ & $(1.00)$ & $\mathrm{n} / \mathrm{a}$ & $(1.00)$ & $\mathrm{n} / \mathrm{a}$ & $(1.00)$ & $\mathrm{n} / \mathrm{a}$ \\
\hline $8-11$ & $1.87 *$ & $\mathrm{n} / \mathrm{a}$ & $-0.12 * * *$ & $\mathrm{n} / \mathrm{a}$ & -0.04 & $\mathrm{n} / \mathrm{a}$ \\
\hline \multicolumn{7}{|l|}{ Race/ethnicity } \\
\hline African-American & $2.23 *$ & 1.31 & 0.02 & 0.02 & 0.04 & $0.13^{*}$ \\
\hline White & $(1.00)$ & $(1.00)$ & $(1.00)$ & $(1.00)$ & $(1.00)$ & $(1.00)$ \\
\hline Latino & 0.82 & 1.07 & -0.13 & -0.07 & -0.05 & -0.03 \\
\hline Other & 0.79 & 1.41 & 0.07 & -0.02 & 0.10 & 0.03 \\
\hline \multicolumn{7}{|l|}{ Child's Health Status } \\
\hline Excellent & 1.42 & 0.78 & 0.16 & 0.26 & $0.22 *$ & 0.19 \\
\hline Very good & 0.93 & 0.73 & 0.10 & $0.28^{*}$ & $0.20^{*}$ & 0.15 \\
\hline Good & 0.96 & 0.88 & 0.04 & 0.12 & 0.11 & 0.12 \\
\hline Fair or Poor & $(1.00)$ & $(1.00)$ & $(1.00)$ & $(1.00)$ & $(1.00)$ & $(1.00)$ \\
\hline \multicolumn{7}{|l|}{$\begin{array}{l}\text { Parent/Guardian } \\
\text { Characteristics }\end{array}$} \\
\hline \multicolumn{7}{|l|}{ Gender } \\
\hline Male & $(1.00)$ & $(1.00)$ & $(1.00)$ & $(1.00)$ & $(1.00)$ & $(1.00)$ \\
\hline Female & 0.53 & 0.53 & -0.01 & 0.05 & -0.06 & 0.01 \\
\hline \multicolumn{7}{|l|}{ Educational Attainment } \\
\hline $\begin{array}{l}\text { Did not graduate from } \\
\text { high school }\end{array}$ & $2.55^{*}$ & 0.74 & 0.08 & -0.04 & 0.06 & 0.07 \\
\hline $\begin{array}{l}\text { Graduated from high } \\
\text { school }\end{array}$ & $2.24 * *$ & 1.09 & 0.01 & 0.00 & 0.01 & 0.01 \\
\hline $\begin{array}{l}\text { Attended at least some } \\
\text { college }\end{array}$ & $(1.00)$ & $(1.00)$ & $(1.00)$ & $(1.00)$ & $(1.00)$ & $(1.00)$ \\
\hline \multicolumn{7}{|l|}{ Household has car } \\
\hline Yes & $0.37 * * *$ & 0.60 & -0.00 & -0.10 & -0.09 & -0.06 \\
\hline No & $(1.00)$ & $(1.00)$ & $(1.00)$ & $(1.00)$ & $(1.00)$ & $(1.00)$ \\
\hline
\end{tabular}


Table 3.8 Multivariate Models Examining Built-Environment Predictors of Physical Activity, By Perceived Neighborhood Safety

\begin{tabular}{|c|c|c|c|c|c|c|}
\hline & \multicolumn{2}{|c|}{$\begin{array}{l}\text { Regularly Walks or } \\
\text { Bikes to School } \\
\text { (Odds Ratios) }\end{array}$} & \multicolumn{2}{|c|}{$\begin{array}{c}\text { Days per Week } \\
\text { Vigorous Exercise } \\
\text { (Poisson Coefficient) }\end{array}$} & \multicolumn{2}{|c|}{$\begin{array}{c}\text { Days per Week } \\
\text { Walking } \\
\text { (Poisson Coefficient) }\end{array}$} \\
\hline & $\begin{array}{c}\text { Safe } \\
\text { Neighbor- } \\
\text { hood } \\
(\mathrm{n}=378)\end{array}$ & $\begin{array}{c}\text { Less-Safe } \\
\text { Neighbor- } \\
\text { hood } \\
(\mathrm{n}=340)\end{array}$ & $\begin{array}{c}\text { Safe } \\
\text { Neighbor- } \\
\text { hood } \\
(\mathrm{n}=399)\end{array}$ & $\begin{array}{c}\text { Less-Safe } \\
\text { Neighbor- } \\
\text { hood } \\
(\mathrm{n}=350)\end{array}$ & $\begin{array}{c}\text { Safe } \\
\text { Neighbor- } \\
\text { hood } \\
(\mathrm{n}=391)\end{array}$ & $\begin{array}{c}\text { Less-Safe } \\
\text { Neighbor- } \\
\text { hood } \\
(\mathrm{n}=345)\end{array}$ \\
\hline \multicolumn{7}{|l|}{ Built Environment } \\
\hline $\begin{array}{l}\text { Ratio of Major/Minor } \\
\text { Roads }\end{array}$ & 0.01 & 0.05 & -0.24 & $1.07 * *$ & -0.12 & 0.69 \\
\hline Intersection Density & 1.00 & $1.01 *$ & -0.00 & 0.00 & -0.00 & 0.00 \\
\hline Dead-end Density & 1.02 & 1.01 & 0.00 & 0.00 & -0.00 & -0.00 \\
\hline Residential Density & 1.00 & 1.00 & -0.00 & -0.00 & 0.00 & 0.00 \\
\hline \multicolumn{7}{|l|}{ Child's Characteristics } \\
\hline \multicolumn{7}{|l|}{ Gender } \\
\hline Boy & $(1.00)$ & $(1.00)$ & $(1.00)$ & $(1.00)$ & $(1.00)$ & $(1.00)$ \\
\hline Girl & 1.03 & 0.93 & -0.05 & $-0.14 * * *$ & -0.13 & -0.01 \\
\hline \multicolumn{7}{|l|}{ Age } \\
\hline $4-7$ & $(1.00)$ & $\mathrm{n} / \mathrm{a}$ & $(1.00)$ & $(1.00)$ & $(1.00)$ & $(1.00)$ \\
\hline $8-11$ & 1.32 & $2.24 *$ & $-0.12 * *$ & $-0.14 * *$ & -0.00 & -0.07 \\
\hline $12-18$ & 0.93 & 1.76 & $-0.17 * *$ & $-0.18 * * *$ & 0.07 & -0.07 \\
\hline \multicolumn{7}{|l|}{ Race/ethnicity } \\
\hline African-American & $2.35^{*}$ & 1.42 & 0.04 & 0.02 & 0.08 & 0.08 \\
\hline White & $(1.00)$ & $(1.00)$ & $(1.00)$ & $(1.00)$ & $(1.00)$ & $(1.00)$ \\
\hline Latino & 0.90 & 0.93 & -0.12 & -0.07 & -0.03 & 0.02 \\
\hline Other & 1.33 & 1.15 & 0.01 & 0.05 & -0.02 & 0.14 \\
\hline \multicolumn{7}{|l|}{ Child's Health Status } \\
\hline Excellent & 0.79 & 1.30 & 0.15 & 0.23 & 0.22 & 0.14 \\
\hline Very good & 0.65 & 1.00 & 0.12 & 0.21 & 0.15 & 0.19 \\
\hline Good & 1.00 & 0.92 & 0.01 & 0.15 & 0.15 & 0.04 \\
\hline Fair or Poor & $(1.00)$ & $(1.00)$ & $(1.00)$ & $(1.00)$ & $(1.00)$ & $(1.00)$ \\
\hline \multicolumn{7}{|l|}{$\begin{array}{l}\text { Parent/Guardian } \\
\text { Characteristics }\end{array}$} \\
\hline \multicolumn{7}{|l|}{ Gender } \\
\hline Male & $(1.00)$ & $(1.00)$ & $(1.00)$ & $(1.00)$ & $(1.00)$ & $(1.00)$ \\
\hline Female & $0.44 *$ & 0.66 & -0.06 & 0.09 & -0.08 & -0.07 \\
\hline \multicolumn{7}{|l|}{ Educational Attainment } \\
\hline $\begin{array}{l}\text { Did not graduate from } \\
\text { high school }\end{array}$ & 1.36 & 1.54 & 0.04 & 0.03 & 0.09 & 0.10 \\
\hline $\begin{array}{l}\text { Graduated from high } \\
\text { school }\end{array}$ & 1.20 & $2.04 *$ & -0.02 & 0.04 & -0.05 & 0.07 \\
\hline $\begin{array}{l}\text { Attended at least some } \\
\text { college }\end{array}$ & $(1.00)$ & $(1.00)$ & $(1.00)$ & $(1.00)$ & $(1.00)$ & $(1.00)$ \\
\hline \multicolumn{7}{|l|}{ Household has car } \\
\hline Yes & $0.35 * *$ & $0.63^{*}$ & $-0.11 *$ & 0.01 & $-0.14 * *$ & -0.03 \\
\hline No & $(1.00)$ & $(1.00)$ & $(1.00)$ & $(1.00)$ & $(1.00)$ & $(1.00)$ \\
\hline
\end{tabular}




\subsection{DISCUSSION}

This study examined the extent to which neighborhood built-environment and safety factors were related to active transportation and other forms of physical activity among a population of lowincome, ethnically diverse children. The analysis found that the built-environment factors, which included the ratio of major to minor roads, dead-end density, and residential density, were not independent predictors of physical activity in multivariate models. For those who lived in lower-safety neighborhoods, however, the greater the intersection density in a zip code, the more likely children were to walk or bike regularly to school.

Neighborhood safety was a more consistent predictor of physical activity in this study. In neighborhoods where parents reported that there was a safe, outdoor place for children to play, children more frequently engaged in vigorous exercise. Children in these neighborhoods were also more likely to participate in sports teams and classes. The second finding, which is less intuitive, may be due to more physical activity-related opportunities being available in safe neighborhoods and/or parents feeling more comfortable sending their children to participate in teams/classes in safer neighborhoods.

The lack of a consistent relationship between the built-environment factors and physical activity in this study may be due to several factors. One possible explanation is that zip-code level measures of the built environment were used. While the zip codes in these generally urban areas were small (half a mile on average), zip-code boundaries may not accurately reflect actual neighborhood boundaries. It is also possible that the lack of relationship is due to the fact that alow-income, urban sample of children were studied and that, for this subgroup, safety is a more important factor than the built environment. Future research should compare the built environments' relationship to physical activity between low-income children and middle-income children.

The study findings point to the potential role of public safety in influencing physical activity. While only a cross-sectional study, the findings suggest that improving neighborhood safety may increase children's physical-activity levels. However, the public entities responsible for children's health are not those responsible for neighborhood safety. This dynamic will likely present policy challenges.

The results of this study confirm a larger body of literature that shows that adolescents engage in less vigorous exercise than do younger children. Interestingly, older children are more likely to participate in sports teams and classes. The study also points to the influence of race/ethnicity on certain measures of physical activity. Latino children were significantly less likely to engage in physical activity compared with whites or African-Americans. African-Americans, in contrast, were more likely to regularly walk or bike to school than whites. Since this study largely controls for socio-economic status, these findings suggest there are cultural differences in physical activity by racial and ethnic groups. Future research should examine this issue beyond the setting in Florida where this study was conducted. 
In summary, in this examination of environmental factors on physical activity among lowincome children, perceived neighborhood safety was a more important predictor of physical activity than were measures of the built environment. Future research examining the built environment's influence on physical activity should incorporate measures of neighborhood safety, and policymakers should consider public safety as an approach to improving physical activity in low-income neighborhoods. 


\subsection{REFERENCES}

L.M. Alexander, J. Inchley, et al. (2005). "The broader impact of walking to school among adolescents: seven day accelerometry based study." British Medical Journal 331(7524): 1061-1062.

P. Allison (1991). Logistic regression using the SAS system. Cary, NC, SAS.

Bloom B and C. Ra (2007). Summary Health Statistics for U.S. Children: National Health Interview Survey, 2006. National Center for Health Statistics.

M. Braza, W. Shoemaker, et al. (2004). "Neighborhood design and rates of walking and biking to elementary school in 34 California communities." American Journal of Health Promotion 19(2): 128-136.

R.C. Brownson, E.A. Baker, et al. (2001). "Environmental and policy determinants of physical activity in the United States." American Journal of Public Health 91(12): 1995-2003.

H. Committee on Physical Activity, Transportation, and Land Use, (2005). Does the Built Environment Influence Physical Activity? Examining the Evidence. Washington DC, Transportation Research Board and Institute of Medicine.

A.R. Cooper, A.S. Page, et al. (2003). "Commuting to school: are children who walk more physically active?" American Journal of Preventive Medicine 25(4): 273-276.

K. Day and B. Cardinal (2007). "A Second Generation of Active Living Research." American Journal of Health Promotion 21(4): iv-vii.

W.H. Dietz (1998). "Health consequences of obesity in youth: childhood predictors of adult disease." Pediatrics 101(3) Pt 2: 518-525.

S. Doyle, A. Kelly-Schwartz, et al. (2006). "The Relationship of Walkable and Safe Communities to Invdividual Health." Journal of the American Planning Association 72(1): 19-31.

R. Ewing (2005). "Can the physical Environment Determine Physical Activity Levels." Exercise and Sport Sciences Reviews 33(2): 69-75.

R. Ewing, T. Schmid, et al. (2003). "Relationship between urban sprawl and physical activity, obesity, and morbidity." American Journal of Health Promotion 18(1): 47-57.

S.S. Guo, A.F. Roche, et al. (1994). "The predictive value of childhood body mass index values for overweight at age 35 y." American Journal of Clinical Nutrition 59(4): 810-819. 
P. Hu and T. Reuscher (2004). Summary of Travel Trends: 2001 National Household Travel Survey. Washington, DC, United States Department of Transportation.

A. Kelly-Schwartz, J. Stockard, et al. (2004). "Is sprawl unhealthy? A multi-level analysis of the relationship of metropolitan sprawl to the health of individuals." Journal of Planning Education and Research 24(2): 184-196.

J. Koplan, C. T. Liverman, et al. (2004). Preventing Childhood Obesity: Health in the Balance. Washington, DC, Institute of Medicine.

C. Lee (2007). "Environment and active living: the roles of health risk and economic factors." American Journal of Health Promotion 21(4 Supplement): 293-304.

T. Mcmillan (2003). "Walking and urban form: modeling and testing parental decisions about children's travel." Unpublished doctoral dissertation University of California, Irvine.

B. Metcalf, Voss L, et al. (2004). "Physical Activity Cost of the School Run: Impact on Schoolchildren of Being Driven to School." British Medical Journal 329: 832-833.

A.H. Mokdad, J.S. Marks, et al. (2004). "Actual causes of death in the United States, 2000." Journal of the American Medical Association 291(10): 1238-1245.

B. Molnar, S. Gortmaker, et al. (2004). "Unsafe to Play? Neighborhood Disorder and Lack of Safety Predict Reduced Physical Activity Among Urban Children and Adolescents." 18 5(378-86).

C.L. Ogden, M.D. Carroll, et al. (2006). "Prevalence of Overweight and Obesity in the United States, 1999-2004." Journal of the American Medical Association 295(13): 1549-1555.

M. Schlossberg, J. Greene, et al. (2006). "School Trips: Effects of Urban Form and Distance on Travel Mode." Journal of the American Planning Association 72(3): 337-346.

R. Sturm (2005). "Childhood obesity -- what we can learn from existing data on societal trends, part 2." Prevention of Chronic Disease 2(2): A20.

S.G. Trost, N. Owen, et al. (2002). "Correlates of adults' participation in physical activity: review and update." Medicine and Science in Sports and Exercise 34(12): 1996-2001.

U.S. Department of Health and Human Resources (2003). 2003 National Survey of Children's Health Child and Adolescent Health Measurement Initiative,.

Us Census Bureau (2008). Statistical Abstract of the United States, 2007. Washington, DC, Library of Congress.

Y. Wang and M.A. Beydoun (2007). "The obesity epidemic in the United States--gender, age, socioeconomic, racial/ethnic, and geographic characteristics: a systematic review and meta-regression analysis." Epidemiologic Reviews 29: 6-28. 


\subsection{APPENDICES}

Table 6.1 Correlations Among Physical-Activity Measures, Children Ages 5-11 (n=444)

\begin{tabular}{l|c|c|c|c}
\hline & $\begin{array}{c}\text { Regularly } \\
\text { Walks or Bikes } \\
\text { to School }\end{array}$ & $\begin{array}{c}\text { Days per Week } \\
\text { Walking 10 or } \\
\text { More Minutes }\end{array}$ & $\begin{array}{c}\text { Days per Week } \\
\text { Vigorous } \\
\text { Exercise }\end{array}$ & $\begin{array}{c}\text { Participates in } \\
\text { Sports Teams } \\
\text { or Exercise or } \\
\text { Classes }\end{array}$ \\
\hline $\begin{array}{l}\text { Regularly Walks or Bikes to } \\
\text { School }\end{array}$ & 1.00 & $0.14^{* *}$ & 0.08 & -0.00 \\
\hline $\begin{array}{l}\text { Days per Week Walking 10 } \\
\text { or More Minutes }\end{array}$ & 1.00 & $0.31^{* *}$ & 0.01 \\
\hline $\begin{array}{l}\text { Days per Week Vigorous } \\
\text { Exercise }\end{array}$ & & 1.00 & 0.07 \\
\hline $\begin{array}{l}\text { Participates in Sports Teams } \\
\text { or Classes }\end{array}$ & & & & 1.00 \\
\hline *p $<.05 * * \mathrm{p}<.01$ & & &
\end{tabular}

Table 6.2 Correlations Among Physical-Activity Measures, Children Ages 11-18 ( $\mathrm{n}=315)$

\begin{tabular}{l|c|c|c|c}
\hline & $\begin{array}{c}\text { Regularly } \\
\text { Walks or Bikes } \\
\text { to School }\end{array}$ & $\begin{array}{c}\text { Days per Week } \\
\text { Walking 10 or } \\
\text { More Minutes }\end{array}$ & $\begin{array}{c}\text { Days per Week } \\
\text { Vigorous } \\
\text { Exercise }\end{array}$ & $\begin{array}{c}\text { Participates in } \\
\text { Sports Teams } \\
\text { or Exercise or } \\
\text { Classes }\end{array}$ \\
\hline $\begin{array}{l}\text { Regularly Walks or Bikes to } \\
\text { School }\end{array}$ & 1.00 & 0.05 & 0.01 & -0.00 \\
\hline $\begin{array}{l}\text { Days per Week Walking 10 } \\
\text { or More Minutes }\end{array}$ & 1.00 & $0.34^{* *}$ & 0.10 \\
\hline $\begin{array}{l}\text { Days per Week Vigorous } \\
\text { Exercise }\end{array}$ & & & 1.00 & $0.11^{*}$ \\
\hline $\begin{array}{l}\text { Participates in Sports Teams } \\
\text { or Classes }\end{array}$ & & & & 1.00 \\
\hline${ }^{*} \mathrm{p}<.05 * * \mathrm{p}<.01$ & & &
\end{tabular}


Table 6.3 Correlations Among Physical-Activity Measures, Girls $(n=413)$

\begin{tabular}{l|c|c|c|c}
\hline & $\begin{array}{c}\text { Regularly } \\
\text { Walks or Bikes } \\
\text { to School } \\
\text { Walking 10 or } \\
\text { More Minutes }\end{array}$ & $\begin{array}{c}\text { Days per Week } \\
\text { Vigorous } \\
\text { Exercise }\end{array}$ & $\begin{array}{c}\text { Participates in } \\
\text { Sports Teams } \\
\text { or Exercise or } \\
\text { Classes }\end{array}$ \\
\hline $\begin{array}{l}\text { Regularly Walks or Bikes to } \\
\text { School }\end{array}$ & 1.00 & $0.15^{* *}$ & 0.05 & 0.05 \\
\hline $\begin{array}{l}\text { Days per Week Walking 10 } \\
\text { or More Minutes }\end{array}$ & & 1.00 & $0.33^{* *}$ & 0.05 \\
\hline $\begin{array}{l}\text { Days per Week Vigorous } \\
\text { Exercise }\end{array}$ & & & 1.00 & 0.00 \\
\hline $\begin{array}{l}\text { Participates in Sports Teams } \\
\text { or Classes }\end{array}$ & & & & 1.00 \\
\hline
\end{tabular}

$* \mathrm{p}<.05 * * \mathrm{p}<.01$

Table 6.4 Correlations Among Physical-Activity Measures, Boys $(\mathrm{n}=382)$

\begin{tabular}{l|c|c|c|c}
\hline & $\begin{array}{c}\text { Regularly } \\
\text { Walks or Bikes } \\
\text { to School } \\
\text { Walking 10 or } \\
\text { More Minutes }\end{array}$ & $\begin{array}{c}\text { Days per Week per Week } \\
\text { Vigorous } \\
\text { Exercise }\end{array}$ & $\begin{array}{c}\text { Participates in } \\
\text { Sports Teams } \\
\text { or Exercise or } \\
\text { Classes }\end{array}$ \\
\hline $\begin{array}{l}\text { Regularly Walks or Bikes to } \\
\text { School }\end{array}$ & 1.00 & 0.06 & 0.03 & -0.05 \\
\hline $\begin{array}{l}\text { Days per Week Walking 10 } \\
\text { or More Minutes }\end{array}$ & & 1.00 & $0.29 * *$ & 0.06 \\
\hline $\begin{array}{l}\text { Days per Week Vigorous } \\
\text { Exercise }\end{array}$ & & & 1.00 & 0.06 \\
\hline $\begin{array}{l}\text { Participates in Sports Teams } \\
\text { or Classes }\end{array}$ & & & & 1.00 \\
\hline$* p<.05 * * p<.01$ & & &
\end{tabular}


Appendix, Table 6.5. Multivariate Model Examining Built-Environment and Neighborhood-Safety Predictors of Active Transportation, Among Children of Elementary-School Age Who Live Within 15-Minute Walk of Elementary School

\begin{tabular}{|c|c|}
\hline & $\begin{array}{l}\text { Regularly Walks } \\
\text { or Bikes to School } \\
\qquad \begin{array}{c}(\mathrm{n}=223) \\
\text { (Odds Ratios) }\end{array}\end{array}$ \\
\hline \multicolumn{2}{|l|}{ Built Environment } \\
\hline $\begin{array}{l}\text { Ratio of Major/Minor } \\
\text { Roads }\end{array}$ & 0.00 \\
\hline Intersection Density & 1.00 \\
\hline Dead-end Density & 1.02 \\
\hline Residential Density & 1.00 \\
\hline \multicolumn{2}{|l|}{ Safety } \\
\hline $\begin{array}{l}\text { Safe, outdoor place to } \\
\text { play }\end{array}$ & 0.95 \\
\hline $\begin{array}{l}\text { Not safe to go on walks } \\
\text { during the day }\end{array}$ & 0.93 \\
\hline \multicolumn{2}{|l|}{ Child's Characteristics } \\
\hline \multicolumn{2}{|l|}{ Gender } \\
\hline Boy & $(1.00)$ \\
\hline Girl & 0.88 \\
\hline \multicolumn{2}{|l|}{ Age } \\
\hline $4-7$ & $(1.00)$ \\
\hline $8-11$ & $2.49 *$ \\
\hline \multicolumn{2}{|l|}{ Race/ethnicity } \\
\hline African-American & $2.57 *$ \\
\hline White & $(1.00)$ \\
\hline Latino & 0.56 \\
\hline Other & 0.50 \\
\hline \multicolumn{2}{|l|}{ Child's Health Status } \\
\hline Excellent & 1.58 \\
\hline Very good & 1.29 \\
\hline Good & 1.11 \\
\hline Fair or Poor & $(1.00)$ \\
\hline \multicolumn{2}{|l|}{$\begin{array}{l}\text { Parent/Guardian } \\
\text { Characteristics }\end{array}$} \\
\hline \multicolumn{2}{|l|}{ Gender } \\
\hline Male & $(1.00)$ \\
\hline Female & 0.50 \\
\hline \multicolumn{2}{|l|}{ Educational Attainment } \\
\hline $\begin{array}{l}\text { Did not graduate from } \\
\text { high school }\end{array}$ & 2.01 \\
\hline $\begin{array}{l}\text { Graduated from high } \\
\text { school }\end{array}$ & $2.69 *$ \\
\hline $\begin{array}{l}\text { Attended at least some } \\
\text { college }\end{array}$ & $(1.00)$ \\
\hline \multicolumn{2}{|l|}{ Household has car } \\
\hline Yes & $0.28 * *$ \\
\hline No & $(1.00)$ \\
\hline
\end{tabular}




\section{SOTREC \\ AND EDUCATION CONSORTIUM}

P.O. Box 751

Portland, OR 97207

OTREC is dedicated to stimulating and conducting collaborative multi-disciplinary research on multi-modal surface transportation issues, educating a diverse array of current practitioners and future leaders in the transportation field, and encouraging implementation of relevant research results. 